\title{
CORRECTION
}

\section{Correction to: On the nordic guidelines for life cycle assessment}

\author{
Göran Finnveden ${ }^{1} \cdot$ Lars-Gunnar Lindfors $^{1}$
}

Published online: 23 December 2021

(c) Springer-Verlag GmbH Germany, part of Springer Nature 2021

\section{Correction to: The International Journal of Life Cycle Assessment (1996) 1:45-48 https://doi.org/10.1007/BF02978635}

Unfortunately the name of the first author was misspelled in the $\mathrm{xml}$ - version.

Publisher's Note Springer Nature remains neutral with regard to jurisdictional claims in published maps and institutional affiliations.

Göran Finnveden

1 IVI. (Swedish Environmental Research Institute),

PO. Box 21060, 10031 Stockholm, Sweden 